\title{
Channel processes of a small river heavily modified by human activities
}

\author{
Aleksandr Varenov ${ }^{1}$, Anna Tarbeeva ${ }^{2, *}$, Dmitriy Botavin ${ }^{2}$, Nadezhda Mikhaylova ${ }^{2}$, Leonid \\ Turykin $^{2}$, and Aleksandra Chalova ${ }^{2}$ \\ ${ }^{1}$ Nizhniy Novgorod State Reserve Museum of History and Architecture, 7 Verhne-Volzhskaya Emb., \\ 603005, Nizhniy Novgorod, Russia \\ ${ }^{2}$ Lomonosov Moscow State University, 1 Leninskiye Gory, 119991, Moscow, Russia
}

\begin{abstract}
Widely-spread small rivers are very poorly studied in relation to channel processes. The influence of local factors, high sensitivity to human impact, close connection with basin processes, and relatively low rates of channel changes distinguish them from medium and large ones and make it necessary to form a special approach to studies. Based on collection of long-term maps and local residents' interviews, we reconstructed the transformation of channels in the Kudma River basin (the Volga Upland) for the last 200 years. Based on the bank erosion monitoring during 2011-2019 the modern rates of channel changes were revealed. We found that significant human impact is associated with the artificial channels cutoffs and draining of ponds which led to channel incision of the Kudma and Ozerka Rivers in the middle reaches and the transformation of floodplain into terrace. Agriculture development caused siltation of the upper reaches of rivers. The rivers of the forested part of the basin experienced the least human changes. From 2011 to 2019 the maximum rates of bank erosion were found to be within range of 0.3 to 2.7 $\mathrm{m} /$ year and supposed to be driven by peak water discharge.
\end{abstract}

\section{Introduction}

Small rivers are very poorly studied in relation to channel processes, as they are influenced by many natural and anthropogenic factors. Meanwhile, due to the wide distribution of small rivers human activity is most often associated with them, especially in agricultural areas. Pastures and arable lands are located in the rivers floodplains, ponds are constructed on the rivers for reclamation, fishing or fire fighting purposes, the channels of small rivers are straightened, and the floodplains are drained during land reclamation. That leads to significant changes in channel morphology and dynamics and water regime of small rivers. Over long-term history of the Volga Upland development, small rivers have been significantly changed.

On small rivers periodic channel surveys are not carried out and hardly ever there are hydrological posts where flow rates and water levels are measured. In addition, temporary dams or other structures created on certain river reaches are not reflected on maps and

\footnotetext{
* Corresponding author: amtarbeeva@yandex.ru
} 
plans, and their purpose, dimensions and time of existence can be found out only through field observations or from local residents. Therefore, the study of channel processes on small rivers requires a special approach and field works.

The aim of our study was to identify the patterns and extent of changes in channel morphology and dynamics of a small river under long-term anthropogenic influence. Case study area is the Kudma River basin (catchment area $3220 \mathrm{~km}^{2}$ ) - the right tributary of the Volga River near the settlement Kstovo.

The Kudma River basin is located within the moraine plain, which passes southeast into a gently sloping fluvioglacial plain [1]. In the western part of the basin there is karst development, including channels of rivers. The western part of the Kudma River basin is forested. The rest of the catchment area is predominantly plowed. The total forest cover of the basin is $27.3 \%$. A variety of environmental conditions and varying degrees and patterns of human development of different parts of the basin made it possible to trace the role of each type of impact.

The length of the Kudma River is $144 \mathrm{~km}$, its main tributary is the river Ozerka $-74 \mathrm{~km}$. During high water period up to $60-80 \%$ of the annual runoff passes [1]. Average annual water discharge of the Kudma River above the confluence with the Ozerka River (Kstovo settlement $)-5.57 \mathrm{~m}^{3} / \mathrm{s}$, average annual unit discharge $3.38 \mathrm{l} /\left(\mathrm{s}^{*} \mathrm{~km}^{2}\right)$.

\section{Methods}

Based on multi-time maps [2], materials of the Dalnekonstantinovsky Local History Museum and surveys of local residents the main types of impact on river channels were determined. During field surveys existing engineering structures on rivers or their remains, traces of land reclamation measures - dams, canals on floodplain, debris, etc. are described, the current state of river channels is characterized. Based on field and archive materials, the history of human use of the river basin was reconstructed; the zoning of the basin was developed according to the types of human impact on channels, direction of vertical channel changes and channel pattern plan form changes [3, 4].

To identify specific channel changes in 2011 there were organized 15 field stations to study the processes of bank erosion on different rivers of the basin. For the period 20112019 bank erosion mechanisms and rates are evaluated, bed load composition is determined. Estimation of bank erosion rates were carried out by measuring with a tape measure from fixed benchmarks, by tacheometric survey, and in 2019 using an unmanned aerial vehicle, which allowed to reduce the time of field works and improve accuracy of bank erosion measurements. Data of bank erosion rates are compared with the data of maximum water discharge obtained from the Kstovo hydrological station (the Kudma River), as well as the patterns of channel change.

\section{Results}

\subsection{Channel changes for the historical period}

Common to the rivers of the Volga Upland area, the Kudma River and its tributaries have been changed under human influence over the past 200 years [5]. In the second half of the XVIII century the main type of impact was construction of permanent and temporary dams for mills, sawmills, agriculture, fishery and fire fighting purposes: their number by the middle of the XIX century reached thirty, most of them were in the forest part of the basin, in the upper Kudma River. Dams regulated water flow (reduced the flow rate at high water period and increased the flow rate at low water), determined the distribution of zones of 
channel incision and sediment accumulation. However, these dams did not lead to significant channel changes: by the 1930s most of the old dams in the forest part of the basin were destroyed; now we observe the remains of dams and canals on floodplains overgrown with woody vegetation (Fig. 1). Fire and fishing ponds are preserved mainly in the plowed part of the river basin.

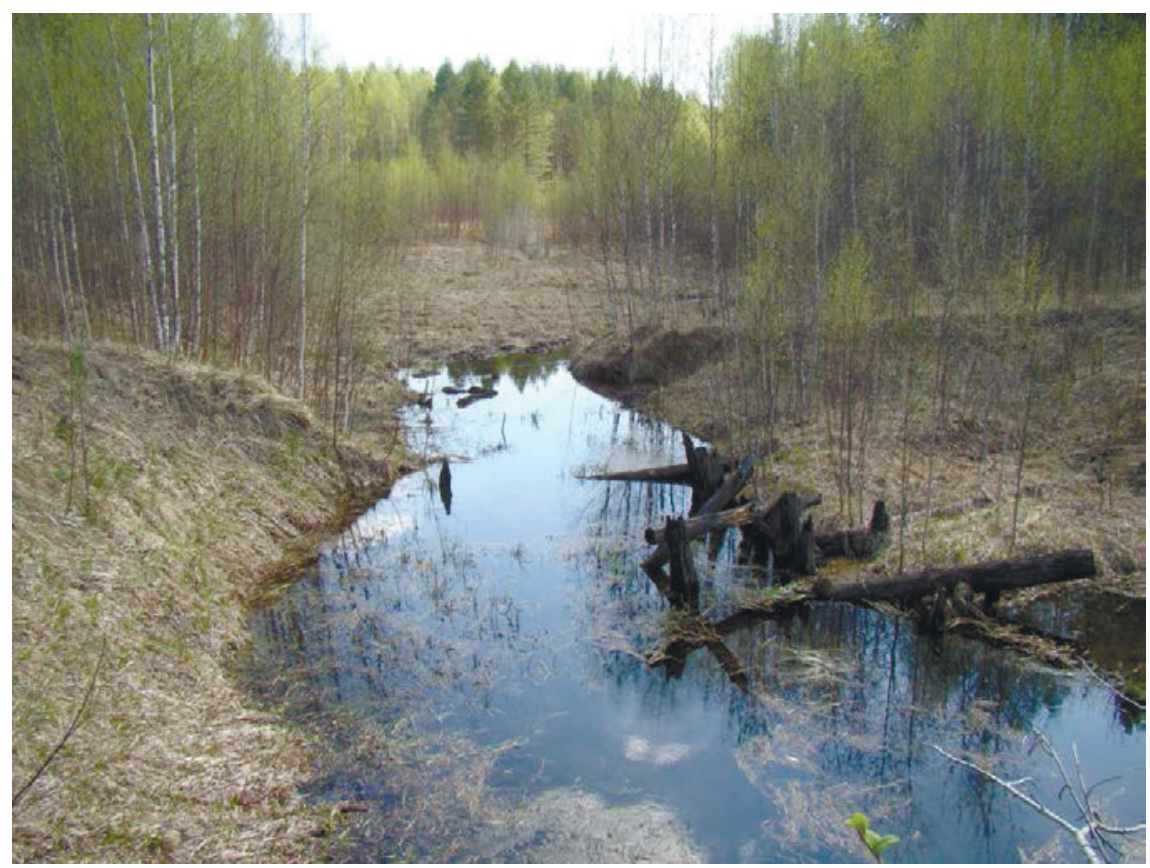

Fig. 1. Remains of a dam in the upper Kudma basin.

Since the middle of the XIX century agricultural development of the territory has been increasing. Accumulation of sediments coming into rivers from plowed watersheds led to channel degradation of the smallest rivers and reduction in the length of river network [6]. On the maps of 1850 [2] the streams are shown as permanent water courses, on modern maps they are temporary, and some of them have disappeared. This process is more typical for the most developed Ozerka River basin; at the present time silted and flank channels are widespread in this part of the basin, water logging of floodplains occurs, that leads to a complete change in the upper river network of the plowed part of the basin.

In the 1930s reclamation activities started, they affected mostly the part of the middle course of the Kudma River basin above the mouth of the Ozerka River. Initially, they were associated with straightening of channels due to development of peat deposits in floodplain. In the middle reaches of the Kudma River complete straightening of the channel was carried out to reduce the flooding of the floodplain, its drainage and plowing. However, later land reclamation measures were carried out in need to irrigate the drained lands: temporary (for the summer period) water-lifting dams and permanent hydro systems for irrigation of vegetable plantations on the Kudma River floodplain were built. These measures led to both direct changes of extended channel reaches by channel straightening, and indirect changes which provided channel incision in middle and lower reaches.

The processes of river incision increased due to the descent of the remaining ponds in the post-Soviet period, when there was a decline in agricultural use of floodplains, no new dams were built. As a result, the channels of the Kudma and Ozerka Rivers incised for 1.5 $\mathrm{m}$ (the average rate was about $1.5-2 \mathrm{~cm}$ per year), which led to its transformation into a low 
terrace (Fig.2). At the same time the channel, with the exception of the straightened reaches, retained its original sinuous shape. On the Ozerka River near the village Belozerovo this led to the appearance of whirlpool zones specific increase of channel width at the tops of bends; in the other areas - to reduction of the length of bank erosion front, general stabilization of the channel.

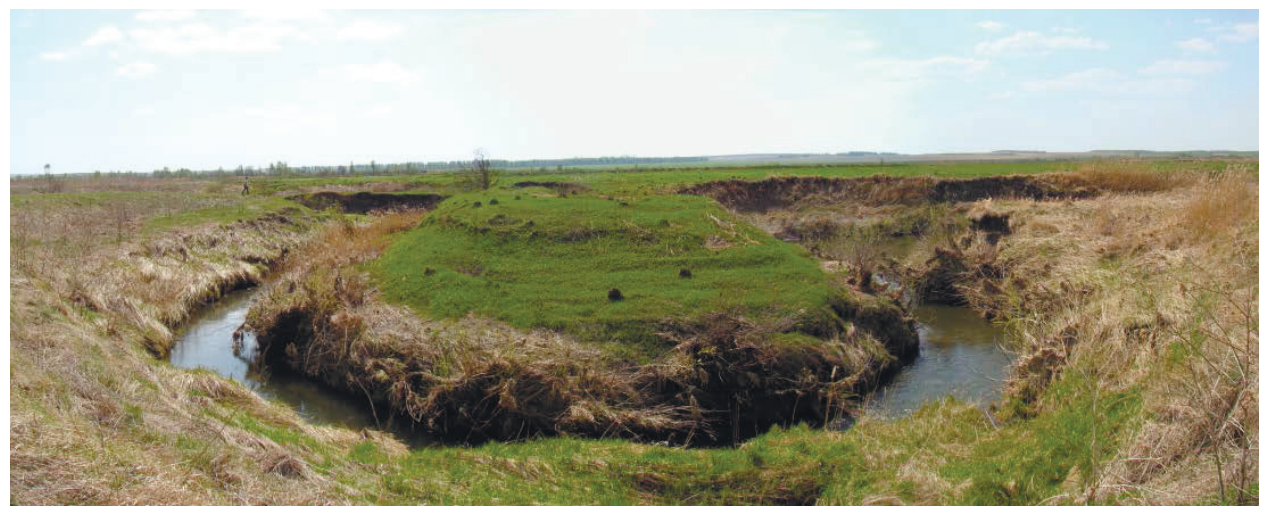

Fig. 2. Incised channel in the middle course of the Ozerka River.

Since 2010, construction of low-pressure reclamation dams, fishery and fire ponds (the upper Kudma River and its tributary the Setchuga River) has resumed. Most of them were built without research and project development; accounting for these facilities is missing. The descent of such ponds in case of dams destruction during flood periods leads to the violent removal of sediments downstream, their deposition in the form of sand ridges, formation of huge silt fields in place of the former ponds where new channels form (Fig. 3).

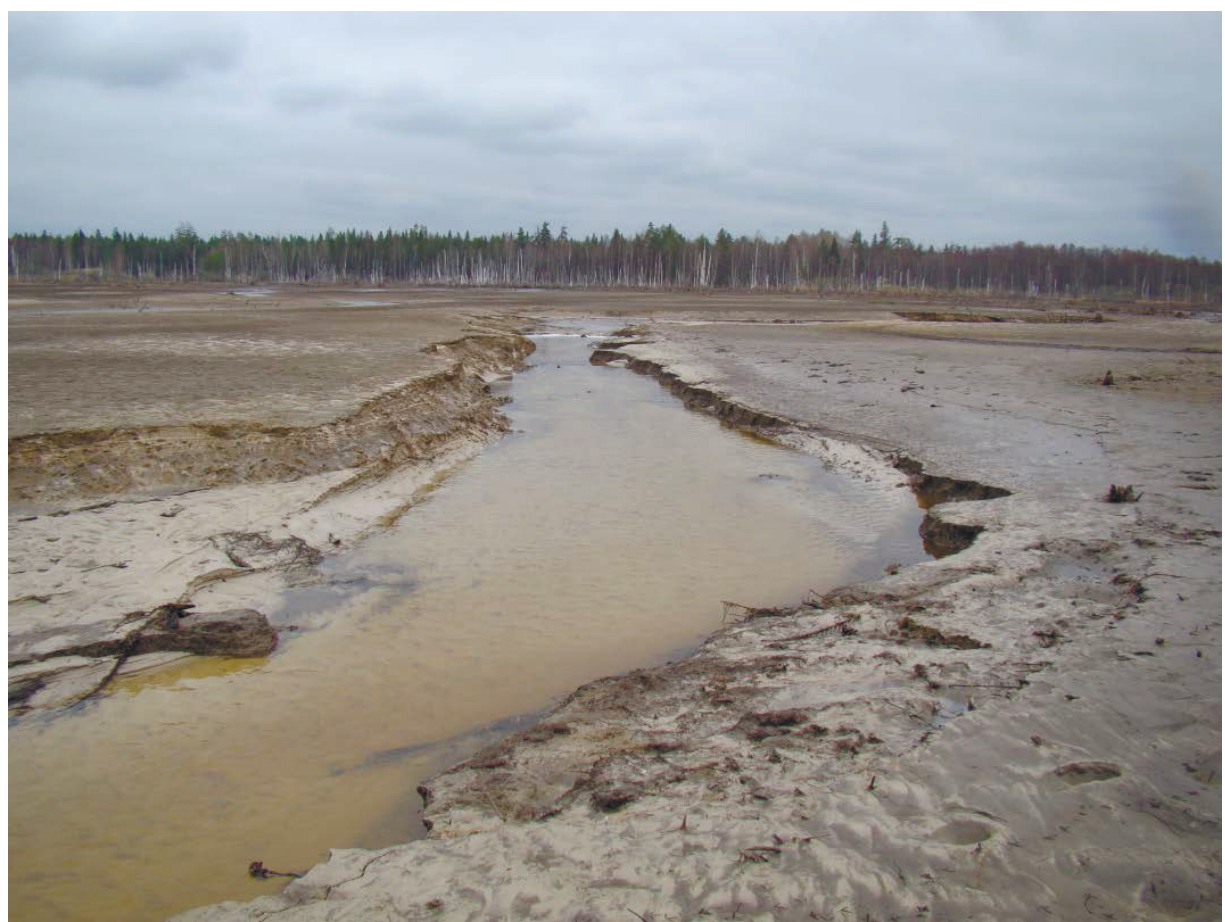

Fig. 3. A new channel forming on a silt field in the place of former pond. 
The lower course of the Kudma River is influenced by floodplain sand quarries and backwater from the Volga River. However, the lower reach could be flooded due to backwater from the Cheboksary water-reservoir, which was not filled up to design marks, so this allowed the lower reach of the Kudma River to remain in a state close to natural. However, the channel deposits here contain abundant silt material.

\subsection{Current channel changes}

Bank erosion monitoring stations were located mainly in the middle and lower reaches of the Kudma and Ozerka Rivers, where the highest values of bank erosion are observed and their traces are well expressed. However, sections of bank erosion are localized at the tops and lower wings of bends and their length relative to the entire length of the bank is no more than $20 \%$. The eroding bank is represented by a high floodplain, which commonly turned into a terrace as a result of river incision.

The maximum-recorded rates of bank erosion were $2.7 \mathrm{~m}$ in the middle reaches of the Kudma River (the Zeleniy Gorod station) and were observed in 2012, when the flood had maximum water content over the entire observation period. In general, for the middle and lower reaches of the rivers there is a good relationship between maximum rates of bank erosion and maximum water discharge of flood period.

However, percent of eroded banks in relation to the total length of banks is maximal on rivers of the forested part of the catchment, where conditions are close to natural. On the floodplain there are numerous abandoned channels which correspond to active development of channel processes. Although absolute values of erosion are small here, due to small size of the rivers, the annual rate of bank erosion is $15-20 \%$ of the channel width, while in the middle and lower reaches it is only $4-5 \%$ of the width. There is only one field station - on the river Setchuga in the village Ivanovskoye. This section is characterized by low, annually flooded banks and fine-grained sandy sediment composition. Similar reaches there are in the upstream of the Kudma river above the village Lesnoye, where stationary observations are not carried out.

\section{Conclusions}

The type of channel changes depends both on the initial natural differences of the rivers within the basin, and on the specifics of rivers use, the character of development of different parts of the basin: the degree of plowing, reclamation measures on the floodplain or backwater processes. The greatest human impacts are associated with artificial channel cutoffs and ponds removal and subsequent floods in the middle reaches of the Kudma and Ozerka rivers, which led to incision of their channels and transformation of floodplain into terrace. Agricultural development of the river basin has caused siltation of the upper reaches of rivers in the developed part of the catchment area; the rivers of the forested part of the basin experienced the least anthropogenic changes. In the lower reaches, due to backwater from the Volga River, siltation of channels occurs.

The maximum rates of plan form changes are determined by maximum water discharges during the flood and are observed in the middle reaches of rivers where channel incision had occurred. However, the sections of bank erosion are limited here; the length of erosion banks does not exceed $4-5 \%$ of the channel width. In the upper reaches of rivers in the forested part of the basin the maximum rate of bank erosion is small, but it reaches up to $20 \%$ of channel width and erosion processes are observed along the entire length of the concave bank of bends, channel changes are rather intensive. In the lower reaches of the Kudma River the erosion rates are also small due to backwater and siltation of the river. 
The reported study was funded by RFBR, projects number 18-05-00487 and contributes to the State Task no. AAAA-A16-116032810084-0, Faculty of Geography MSU.

\section{References}

1. Present landscapes of the Nizhny Novgorod Region. (N.Novgorod: the Publ. of VolgaVyatka Academy of State service. 2006), in Russian

2. A. I. Mende. Nizhny Novgorod province: map. Scale 1:42 000. (St. Petersburg: the Publ. of the RGS. 1850)

3. A. L. Varenov. Geomorphology. 1. 73-82 (2013), in Russian

4. R.S. Chalov, D.V. Botavin, L.A. Varenov, A.S. Zavadskiy, A.M. Tarbeeva. Geography and natural resources. 3. 86-94 (2018), in Russian

5. Small rivers of the Volga River basin (Moscow, the Publ. of the MSU. 1998), in Russian

6. A.P. Dedkov, S.G. Kurbanova, and V.I. Mozzherin Proceedings of the Academy of water management Sciences. 1. 93-98. (1995), in Russian 